\section{Wang goes bust}

The bankruptcy of Wang Laboratories is sad - and confirmation that even the best cannot stand still.

A DECADE ago, none of the glossy business magazines failed to publish a profile of the late An Wang, who, despite his birth in China, had founded Wang Laboratories in the United States and, in the face of indigenous competition, had turned it into a substantial company (the sales, at the peak, exceeding $\$ 3$ billion a year). Wang, the man, had become a legend in his time. At the outset his stock in trade, before the microprocessor revolutionized the computer business in the late 1970s, was to offer commercial businesses access to computer techniques of a kind more commonly found in research laboratories. For a time, Wang installations in office buildings were recognizable by their sophistication. So why, last week, did this paragon of technology sue for bankruptcy under the rules of Chapter 11 of the US bankruptcy legislation (which get creditors off a company's back while it tries to reorganize itself)?

The simple answer is that Wang has been losing money - \$385 million last year, $\$ 130$ million in the most recent financial year (to the end of June). Like many other technologically advanced companies, Wang sustained its growth over two decades by borrowing from the financial markets; the bond holders not unreasonably want to be paid the interest they are owed although the company is losing money. The explanation of Wang's plight can be sought at several different levels. Technically, it is a fact that the minicomputers that were the hard core of its hardware business have been outflanked by desktop machines. (Digital Equipment Corporation, as recently as a decade ago applauded for its VAX minicomputers, is now also in trouble.) The management consultants were also shaking their heads over the degree of An Wang's personal identification (until his death last year) with the company's past success. But who believes that committees of directors are able to respond more quickly than individuals to changing circumstances? The truth is that Wang's management of the company is blamed now simply because it has failed.

What will happen next is anybody's guess. The company hopes to find a continuing role as a superior designer of integrated software systems, but that must be a gamble. For one thing there is already a lot of competition. For another, it is improbable that major companies outside the computer business will indefinitely delegate to outsiders, however skilled, the design of the information management systems on which their own effectiveness depends. But the court supervision required by Chapter 11 would probably not allow Wang to use its technical excellence to strike out in a more adventurous direction.

The wider lessons of Wang's collapse are more deeply buried. Of course, in retrospect, it was a mistake to have made computer systems that were incompatible with those of other manufacturers, but suppose that gamble had paid off? Wang's more serious mistake was to have to set out, in a field in which technology was plainly destined to be quickly changing, to become an integrated company embracing research, development, manufacturing and the selling of the final products. Those are the circumstances in which companies risk being trapped by newly created inertia into products rendered obsolete for reasons beyond their own control. In the United States, the biotechnology industry (or those who invest in it) seems to have sensed the danger, and has remained a collection of research-based companies selling licences (and sometimes themselves) to bigger fish. Much of what is called Silicon Valley seems to have taken the same point. Those who worry about the industrial competitiveness of the United States may find it some comfort that the importance of research-based companies is almost unique to the United States.

\section{Darwin's detractors}

Those persuaded that natural selection is a pack of lies deserve no heip from the serious press.

DARWIN's theory of evolution has never sat comfortably in the minds of those who pretend that science is a myth engendered by the malevolent to disturb the innocent among us. So it is natural, and inevitable, that there should be a steady stream of publications intended to demonstrate to those who already believe evolution to be false that their prejudices are correct. The latest version of the attack on Darwin, The Facts of Life (Fourth Estate, London) is written by one Richard Milton, who is not a creationist. Like others in the field, the book, as the saying goes, seems to be "well researched"; it quotes the experiments of Cairns et al. (Nature 335, 142-145; 1988) as proof of directed rather than undirected evolution, for example.

The appearance of books like this is not remarkable; publishers are free to publish what they choose. But Milton's book has this week been given advance publicity in the British newspaper The Sunday Times under the headline "Scientist threatens to make Darwin extinct". (Milton is described in the text that follows as a "science writer, engineer and amateur geologist"; this is his first book.) The text of the article, taking more than a third of a page, summarizes the "evidence" that the Earth is much younger than commonly supposed. In the tradition of balanced journalism, it also includes supportive comment from a retired bishop and expressions of mild dissent from two geneticists.

Why serious newspapers do this kind of thing is beyond belief. To be sure, these are the dog days in Britain, when domestic politics is in limbo and newspapers preoccupied with the remarkable doings of the royal family. No doubt the newspaper, if asked, would explain that it is merely its public duty to bring to the attention of its readers controversies that, if resolved, would change the intellectual temper of society. But, followed uncritically, as in this case, that is simply a licence to revive spurious and outdated arguments and to dress them up as alive whenever the flow of regular news is slack. That is not a service but a disservice to serious readers. 